\title{
Front Matter: Volume 8688
}

, "Front Matter: Volume 8688," Proc. SPIE 8688, Active and Passive Smart Structures and Integrated Systems 2013, 868801 (7 May 2013); doi: $10.1117 / 12.2021916$

EDIE $\quad$ Event: SPIE Smart Structures and Materials + Nondestructive Evaluation and SPIE. Health Monitoring, 2013, San Diego, California, United States 


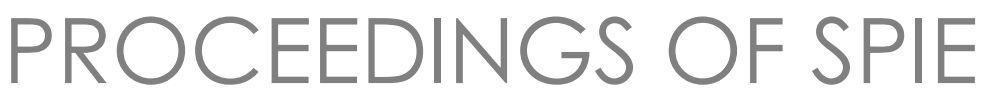

\title{
Active and Passive Smart Structures and Integrated Systems 2013
}

\author{
Henry A. Sodano \\ Editor \\ 10-14 March 2013 \\ San Diego, California, United States \\ Sponsored by \\ SPIE \\ Cosponsored by \\ American Society of Mechanical Engineers (United States) \\ Cooperating Organizations \\ Intelligent Materials Forum (Japan) \\ Jet Propulsion Laboratory (United States) \\ National Science Foundation (United States) \\ Published by \\ SPIE
}


The papers included in this volume were part of the technical conference cited on the cover and title page. Papers were selected and subject to review by the editors and conference program committee. Some conference presentations may not be available for publication. The papers published in these proceedings reflect the work and thoughts of the authors and are published herein as submitted. The publisher is not responsible for the validity of the information or for any outcomes resulting from reliance thereon.

Please use the following format to cite material from this book:

Author(s), "Title of Paper," in Active and Passive Smart Structures and Integrated Systems 2013, edited by Henry A. Sodano, Proceedings of SPIE Vol. 8688 (SPIE, Bellingham, WA, 2013) Article CID Number.

ISSN: 0277-786X

ISBN: 9780819494719

Published by

SPIE

P.O. Box 10, Bellingham, Washington 98227-0010 USA

Telephone +1 3606763290 (Pacific Time) · Fax +1 3606471445

SPIE.org

Copyright (@ 2013, Society of Photo-Optical Instrumentation Engineers.

Copying of material in this book for internal or personal use, or for the internal or personal use of specific clients, beyond the fair use provisions granted by the U.S. Copyright Law is authorized by SPIE subject to payment of copying fees. The Transactional Reporting Service base fee for this volume is $\$ 18.00$ per article (or portion thereof), which should be paid directly to the Copyright Clearance Center (CCC), 222 Rosewood Drive, Danvers, MA 01923. Payment may also be made electronically through CCC Online at copyright.com. Other copying for republication, resale, advertising or promotion, or any form of systematic or multiple reproduction of any material in this book is prohibited except with permission in writing from the publisher. The CCC fee code is 0277-786X/13/\$18.00.

Printed in the United States of America.

Publication of record for individual papers is online in the SPIE Digital Library.

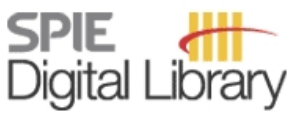

SPIEDigitalLibrary.org

Paper Numbering: Proceedings of SPIE follow an e-First publication model, with papers published first online and then in print and on CD-ROM. Papers are published as they are submitted and meet publication criteria. A unique, consistent, permanent citation identifier (CID) number is assigned to each article at the time of the first publication. Utilization of CIDs allows articles to be fully citable as soon as they are published online, and connects the same identifier to all online, print, and electronic versions of the publication. SPIE uses a six-digit CID article numbering system in which:

- The first four digits correspond to the SPIE volume number.

- The last two digits indicate publication order within the volume using a Base 36 numbering

system employing both numerals and letters. These two-number sets start with 00, 01, 02, 03, 04, $05,06,07,08,09,0 A, 0 B \ldots 0 Z$, followed by 10-1Z, 20-2Z, etc.

The CID Number appears on each page of the manuscript. The complete citation is used on the first page, and an abbreviated version on subsequent pages. Numbers in the index correspond to the last two digits of the six-digit CID Number. 


\section{Contents}

xi Conference Committee

SESSION 1 ENERGY HARVESTING AND SCAVENGING: GENERAL I

868803 Design and performance enhancement of hydraulic pressure energy harvesting systems [8688-3]

E. A. Skow, K. A. Cunefare, A. Erturk, The George W. Woodruff School of Mechanical Engineering (United States)

868804 Piezoelectric PVDF film energy harvester for powering a wireless sensor system [8688-4]

E. Bischur, N. Schwesinger, Technische Univ. München (Germany)

868805 Steady-state dynamics of a bistable energy harvester with linear appendage oscillator [8688-2]

R. L. Harne, M. Thota, K. W. Wang, Univ. of Michigan (United States)

\section{SESSION 2 ENERGY HARVESTING AND SCAVENGING: CIRCUITRY}

868806 Piezoelectric array of oscillators with respective electrical rectification [8688-5]

I. C. Lien, Y. C. Shu, National Taiwan Univ. (Taiwan)

868807 Toward efficient aeroelastic energy harvesting: device performance comparisons and improvements through synchronized switching [8688-6]

M. Bryant, A. D. Schlichting, E. Garcia, Cornell Univ. (United States)

868808 Influence of the topology for a networked SSHI piezoelectric harvesting configuration [8688-7]

Y. Li, D. Guyomar, C. Richard, Lab. de Génie Electrique et de Ferroélectricité, INSA-Lyon,

Univ. de Lyon (France)

868809 Review of power electronics for kinetic energy harvesting systems [8688-8]

P. Li, C. Zhang, L. Zuo, Stony Brook Univ., SUNY (United States)

8688 0A Practical implementation of piezoelectric energy harvesting synchronized switching schemes [8688-9]

A. D. Schlichting, A. Phadke, E. Garcia, Cornell Univ. (United States)

\section{SESSION 3 ENERGY HARVESTING AND SCAVENGING: BROADBAND TECHNIQUES}

$8688 \mathrm{OB}$ Broadband energy harvesting using nonlinear 2-DOF configuration [8688-10]

H. Wu, L. Tang, P. V. Avvari, Y. Yang, C. K. Soh, Nanyang Technological Univ. (Singapore) 
8688 OD Fundamental power limits of piezoelectric energy harvesters based on material strength [8688-12]

M. W. Shafer, E. Garcia, Cornell Univ. (United States)

8688 OE A micro piezoelectric energy harvester based on stainless steel substrate with dual oscillators [8688-13]

C.-C. Wang, Y.-S. Shih, S.-C. Lin, J.-Y. Zeng, W.-J. Wu, National Taiwan Univ. (Taiwan)

8688 OF A multiaxial piezoelectric energy harvester [8688-14]

H. D. Mousselmal, Lab. de Génie Electrique et de Ferroélectricité, INSA-Lyon, Univ. de Lyon (France) and Institut des Nanotechnologies de Lyon, CNRS, Univ. de Lyon (France);

P. J. Cottinet, Lab. de Génie Electrique et de Ferroélectricité, INSA-Lyon, Univ. de Lyon (France); L. Quiquerez, B. Remaki, Institut des Nanotechnologies de Lyon, CNRS, Univ. de Lyon (France); L. Petit, Lab. de Génie Electrique et de Ferroélectricité, INSA-Lyon, Univ. de Lyon (France)

8688 OG A cantilevered piezoelectric bi-stable composite concept for broadband energy harvesting [8688-100]

A. F. Arrieta, T. Delpero, ETH Zürich (Switzerland); A. Bergamini, EMPA (Switzerland);

P. Ermanni, ETH Zürich (Switzerland)

\section{SESSION 4 BIOLOGICAL-INSPIRED SYSTEMS AND BIO-MEMS}

$8688 \mathrm{OH} \quad$ Synthesizing fluidic flexible matrix composite based cellular structures [8688-15]

S. Li, K.-W. Wang, Univ. of Michigan (United States)

SESSION 5 ENERGY HARVESTING AND SCAVENGING: GENERAL II

8688 OK Vibration shape effects on the power output in piezoelectric vibro-impact energy harvesters [8688-18]

J. Twiefel, Leibniz Univ. Hannover (Germany)

$8688 \mathrm{OL}$ Analysis and optimization of thermoacoustic-piezoelectric energy harvesters: an electrical circuit analogy approach [8688-19]

M. Nouh, Univ. of Maryland (United States); O. Aldraihem, King Saud Univ. (Saudi Arabia) and King Abdulaziz City of Science and Technology (Saudi Arabia); A. Baz, Univ. of Maryland (United States)

$86880 \mathrm{M}$ A magnetic/piezoelectric-based thermal energy harvester [8688-20]

T.-K. Chung, National Chiao Tung Univ. (Taiwan); U. Shukla, Banaras Hindu Univ. (India);

C.-Y. Tseng, C.-C. Chen, C.-M. Wang, National Chiao Tung Univ. (Taiwan)

$86880 \mathrm{~N}$ A vibration energy harvester using diamagnetic levitation [8688-21]

S. Palagummi, F. G. Yuan, North Carolina State Univ. (United States) 
SESSION 6 MODELING, SIMULATION, OPTIMIZATION, SIGNAL PROCESSING, CONTROL, AND DESIGN OF INTEGRATION

868800 Identification of flexible structures by frequency-domain observability range context [8688-22]

M. A. Hopkins, Rochester Institute of Technology (United States)

8688 OP Modeling and control of a jellyfish-inspired AUV [8688-23]

C. T. Faria, Virginia Polytechnic Institute and State Univ. (United States) and Univ. of Michigan (United States); S. Priya, Virginia Polytechnic Institute and State Univ. (United States); D. J. Inman, Univ. of Michigan (United States)

$86880 Q$ Computation of 2D vibroacoustic wave's dispersion for optimizing acoustic power flow in interaction with adaptive metacomposites [8688-24]

M. Collet, M. Ouisse, FEMTO-ST (France); M. Ichchou, Lab. de Tribologie et Dynamique des Systèmes, CNRS, Ecole Centrale de Lyon (France); R. Ohayon, 3LMSSC, Conservatoire National des Arts et Métiers (France)

8688 OR Wind farm power maximization based on a cooperative static game approach [8688-25] J. Park, Stanford Univ. (United States); S. Kwon, Chonbuk National Univ. (Korea, Republic of); K. H. Law, Stanford Univ. (United States)

8688 OS Design of smart composite platforms for adaptive trust vector control and adaptive laser telescope for satellite applications [8688-26] M. N. Ghasemi-Nejhad, Univ. of Hawai'i at Manoa (United States)

8688 OT Vibration damping of a cantilever beam utilizing fluidic flexible matrix composites [8688-27]

B. Zhu, C. D. Rahn, C. E. Bakis, The Pennsylvania State Univ. (United States)

$8688 \mathrm{OU} \quad \mathrm{H}_{2}$ optimization of electricity-generating funed mass dampers for simultaneous vibration control and energy harvesting [8688-28]

W. Cui, X. Tang, L. Zuo, Stony Brook Univ., SUNY (United States)

8688 oV A new global approach using a network of piezoelectric elements and energy redistribution for enhanced vibration damping of smart structure [8688-29] D. Wu, D. Guyomar, C. Richard, Lab. de Génie Electrique et de Ferroélectricité, INSA-Lyon, Univ. de Lyon (France)

$8688 \mathrm{OW}$ Experimental investigation of dynamic performance of a prototype hybrid tuned mass damper under human excitation [8688-30]

N. Noormohammadi, P. Reynolds, The Univ. of Sheffield (United Kingdom)

8688 0X Simultaneous supply of infinite and infinitesimal stiffness of active isolation systems that are exposed to multiple vibration sources [8688-31]

B. T. Kletz, Technical Univ. Braunschweig (Germany) and German Aerospace Ctr. (DLR) (Germany); J. Melcher, German Aerospace Ctr. (DLR) (Germany) 
8688 OY Analysis and testing of an inner bypass magnetorheological damper for shock and vibration mitigation [8688-32]

X.-X. Bai, Univ. of Maryland (United States) and Chongaing Univ. (China); W. Hu,

N. M. Wereley, Univ. of Maryland (United States)

$86880 Z$ Modeling of a new magnetorheological elastomer-based isolator [8688-33]

M. Behrooz, X. Wang, F. Gordaninejad, Univ. of Nevada, Reno (United States)

868810 Continuous variable transmission and regenerative braking devices in bicycles utilizing magnetorheological fluids [8688-34]

W. M. Cheung, W.-H. Liao, The Chinese Univ. of Hong Kong (Hong Kong, China)

\section{SESSION 9 SMA- AND PIEZO-BASED MATERIALS AND SYSTEMS}

868812 Simultaneous measurement of longitudinal and lateral piezoelectric strain coefficients using digital image correlation [8688-36]

M. H. Malakooti, H. A. Sodano, Univ. of Florida (United States)

868813 Design and control of direct drive servo-valve operated by the piezostack actuator [8688-37]

J. Jeon, Q.-H. Nguyen, S.-B. Choi, Inha Univ. (Korea, Republic of)

868814 Effect of misalignment between ultrasound piezoelectric transducers on transcutaneous energy transfer [8688-38]

C. Mo, S. Hudson, Washington State Univ. (United States); L. J. Radziemski, Piezo Energy Technologies, LLC (United States)

\section{SESSION $10 \quad$ AIRCRAFT, MAV/UAV AND MORPHING SYSTEMS}

868815 Experimental testing of spanwise morphing trailing edge concept [8688-39]

A. Pankonien, D. J. Inman, Univ. of Michigan (United States)

868818 Characterization of multifunctional skin-material for morphing leading-edge applications [8688-42]

S. Geier, M. Kintscher, T. Mahrholz, P. Wierach, H.-P. Monner, M. Wiedemann, German

Aerospace Ctr. (DLR) (Germany)

\section{SESSION 11 MAGNETO RHEOLOGICAL SYSTEMS II}

868819 A magneto-rheological fluid-based torque sensor for smart torque wrench application [8688-44]

F. Ahmadkhanlou, G. N. Washington, Univ. of California, Irvine (United States) 
8688 1A Simulation of adaptive semi-active magnetorheological seat damper for vehicle occupant blast protection [8688-45]

J.-H. Yoo, M. Murugan, U.S. Army Research Lab. (United States); N. M. Wereley, Univ. of Maryland (United States)

8688 1B Design and control of MR haptic master/slave robot system for minimally invasive surgery [8688-46]

C.-H. Uhm, P.-B. Nguyen, S.-B. Choi, Inha Univ. (Korea, Republic of)

8688 1C An improved polynomial dynamic model of a magnetorheological fluid damper under impact loadings [8688-47]

Z. Li, Nanjing Forestry Univ. (China) and Nanjing Univ. of Science and Technology (China);

J. Zheng, Nanjing Univ. of Science and Technology (China); J. H. Koo, Miami Univ. (United

States); J. Wang, Nanjing Univ. of Science and Technology (China)

8688 1D Energy-efficient MRF clutch avoiding no-load losses [8688-48]

D. Güth, M. Schamoni, J. Maas, Hochschule Ostwestfalen-Lippe Univ. of Applied Sciences (Germany)

$8688 \mathrm{IE}$ Design of the magnetorheological mount with high damping force for medium speed diesel generators [8688-49]

O.-H. Kang, W.-H. Kim, W. H. Joo, Hyundai Heavy Industries Co., Ltd. (Korea, Republic of); J.-H. Park, Inha Univ. (Korea, Republic of)

SESSION 12 ENERGY HARVESTING AND SCAVENGING: GENERAL III

$8688 \mathrm{lF} \quad$ Vibration energy harvesting using Galfenol-based transducer [8688-50]

V. Berbyuk, Chalmers Univ. of Technology (Sweden)

$8688 \mathrm{1H}$ Enhance piezoelectric energy harvesting by stiffness compensation using magnetic effect [8688-52]

J. XU, J. Tang, Univ. of Connecticut (United States)

868811 A hybrid electromagnetic energy harvesting device for low frequency vibration [8688-53] H.-J. Jung, I.-H. Kim, D. Min, KAIST (Korea, Republic of); S.-H. Sim, Ulsan National Institute of Science and Technology (Korea, Republic of); J.-H. Koo, Miami Univ. (United States)

8688 1K Development of a piezoelectric polymer energy harvesting flag [8688-55]

T. Nishigaki, Kinki Univ. (Japan)

8688 1L Highly-integrated energy harvesting device for rotational applications utilizing quasi-static piezoelectric and electromagnetic generators [8688-56]

M. C. Wurz, G. Kleyman, J. Twiefel, Leibniz Univ. Hannover (Germany) 
$8688 \mathrm{iN}$ Investigation of bistable piezo-composite plates for broadband energy harvesting [8688-58]

D. N. Betts, C. R. Bowen, H. A. Kim, N. Gathercole, C. T. Clarke, Univ. of Bath (United Kingdom); D. J. Inman, Univ. of Michigan (United States)

868810 Mechanical and thermal energy transduction utilizing phase transformations in $\mathbf{3 2}$ mode relaxor-ferroelectric single crystals [8688-59]

W. D. Dong, Univ. of California, Los Angeles (United States); P. Finkel, Naval Undersea Warfare Ctr. Newport (United States); C. S. Lynch, Univ. of California, Los Angeles (United States)

\section{SESSION 14 MODELING OF ENERGY HARVESTING SYSTEMS II}

8688 iP Electromechanical and statistical modeling of turbulence-induced vibration for energy harvesting [8688-101]

J. D. Hobeck, D. J. Inman, Univ. of Michigan (United States)

$86881 Q \quad$ Energy harvesting from harmonic and noise excitation of multilayer piezoelectric stacks: modeling and experiment [8688-61]

S. Zhao, A. Erturk, The George W. Woodruff School of Mechanical Engineering (United States)

8688 IR Shear mode energy harvesting of piezoelectric sandwich beam [8688-62] M. H. Malakooti, H. A. Sodano, Univ. of Florida (United States)

8688 is Power-generation prediction for piezoelectric composite plates by modal analysis [8688-63]

Y.-F. Chou, C.-H. Cheng, National Taiwan Univ. (Taiwan)

\section{SESSION $15 \quad$ ADAPTIVE SYSTEMS AND STRATEGIES}

8688 iT Effect of loading rate on the superelastic behavior of SMAs under multi-axial loading conditions; analytical modeling and experiment [8688-64] M. Taheri Andani, M. Elahinia, R. Rahmanian, The Univ. of Toledo (United States)

$86881 \mathrm{U}$ An active control logic to improve the fatigue strength of smart flexible structures [8688-66] P. Ambrosio, F. Braghin, F. Resta, F. Ripamonti, Politecnico di Milano (Italy)

8688 IV On ultrasonic squeeze film levitation: modeling and feedback control of ultrasonic bearing systems [8688-67]

S. Mojrzisch, J. Twiefel, Leibniz Univ. Hannover (Germany)

8688 IW Power fluctuation reduction methodology for the grid-connected renewable power systems [8688-68]

F. T. Aula, S. C. Lee, The Univ. of Oklahoma (United States) 
8688 1X Experimental characterization of a bi-dimensional array of negative capacitance piezopatches for vibroacoustic control [8688-69]

F. Tateo, M. Collet, M. Ouisse, FEMTO-ST (France); M. N. Ichchou, Lab. de Tribologie ef Dynamique des Systèmes, Ecole Centrale de Lyon (France); K. A. Cunefare, The George W. Woodruff School of Mechanical Engineering (United States)

868820 Approximate pole-placement controller using inverse plant dynamics for floor vibration control [8688-72]

D. S. Nyawako, The Univ. of Sheffield (United Kingdom); P. Reynolds, The Univ. of Sheffield (United Kingdom) and Full Scale Dynamics Ltd. (United Kingdom); M. J. Hudson, The Univ. of Sheffield (United Kingdom)

868821 Passive and hybrid piezoelectric circuits to reduce induced-atmospheric turbulence vibration of a plate-like wing [8688-73]

T. M. P. Silva, C. De Marqui, Univ. of Sao Paulo (Brazil)

\section{SESSION 17 PASSIVE AND ACTIVE VIBRATION ISOLATION SYSTEMS III}

868822 Simulation study of semi-active control of stay cable using MR damper under wind loads [8688-74]

J. Liu, Tongji Univ. (China); H. Huang, L. Sun, State Key Lab. for Disaster Reduction in Civil Engineering (China)

868823 A comparison between the IMSC and the DMSC for vibration suppression of smart flexible structures [8688-75]

M. Serra, F. Resta, F. Ripamonti, Politecnico di Milano (Italy)

\section{POSTER SESSION}

868826 Damping properties of stay cable-passive damper system with effects of cable sag and damper stiffness [8688-78]

M. Liu, G. Zhang, Harbin Institute of Technology (China)

868828 A bio-inspired test system for bionic above-knee prosthetic knees [8688-80] D.-H. Wang, L. XU, Q. Fu, G. Yuan, Chongqing Univ. (China)

868829 Theory and experiment research of two-dimension acoustic metamaterial [8688-81] $\mathrm{H}$. Sun, Jiangsu Automation Research Institute (China) and Nanjing Univ. of Science and Technology (China); J. Li, Z. Li, Jiangsu Automation Research Institute (China); Y. Li, Nanjing Univ. of Science and Technology (China)

8688 2A Analysis and modeling of a piezoelectric energy harvester for powering a wireless sensor [8688-82]

M. Bassetti, F. Braghin, D. Milani, F. Ripamonti, G. Tomasini, Politecnico di Milano (Italy) 
8688 2B Modeling and comparison of cantilevered piezoelectric energy harvester with segmented and continuous electrode configurations [8688-83]

H. Wang, Harbin Institute of Technology (China) and Qiqihar Univ. (China); L. Tang, Nanyang Technological Univ. (Singapore); X. Shan, T. Xie, Harbin Institute of Technology (China); Y. Yang, Nanyang Technological Univ. (Singapore)

8688 2C Experimental test of MR fluid based tactile device for minimally invasive surgery [8688-84] J.-S. Oh, J.-K. Kim, S.-B. Choi, Inha Univ. (Korea, Republic of)

$86882 \mathrm{G} \quad$ Fuzzy logic control of the building structure with CLEMR dampers [8688-89]

X.-C. Zhang, Z.-D. XU, X.-H. Huang, J.-T. Zhu, Southeast Univ. (China)

$86882 \mathrm{H} \quad$ Enhancement of piezoelectric energy harvesting with multi-stable nonlinear vibrations [8688-90]

P. V. Avvari, L. Tang, Y. Yang, C. K. Soh, Nanyang Technological Univ. (Singapore)

8688 2J An adaptive non-model-based control strategy for smart structures vibration suppression [8688-92]

M. Morlacchi, F. Resta, F. Ripamonti, G. Tomasini, Politecnico di Milano (Italy)

$86882 \mathrm{~N}$ Electroaeroelastic modeling and analysis of a hybrid piezoelectric-inductive flow energy harvester [8688-96]

J. A. C. Dias, C. De Marqui Jr., Univ. of Sao Paulo (Brazil); A. Erturk, The George W. Woodruff School of Mechanical Engineering (United States)

868820 Application of a passive/active autoparametric cantilever beam absorber with PZT actuator for Duffing systems [8688-97]

G. Silva-Navarro, H. F. Abundis-Fong, Ctr. de Investigación y de Estudios Avanzados del Instituto Politécnico Nacional (Mexico); B. Vazquez-Gonzalez, Univ. Autónoma Metropolitana (Mexico)

8688 2P A fuzzy-logic based dual-purpose adaptive circuit for vibration control and energy harvesting using piezoelectric transducer [8688-98]

Z. P. Liu, Q. Li, Univ. of New Haven (United States)

$86882 Q \quad$ Smart integrated energy monitoring and management system for standalone photovoltaic systems [8688-99]

A. Abou-Elnour, F. S. Murad, I. S. Al-Tayasna, O. Abo-Elnor, Ajman Univ. of Science and Technology (United Arab Emirates)

Author Index 


\section{Conference Committee}

Symposium Chairs

Norbert Meyendorf, Fraunhofer-Institut für Zerstörungsfreie

Prüfverfahren (Germany) and University of Dayton (United States)

Norman Wereley, University of Maryland, College Park (United States)

Symposium Cochairs

Victor Giurgiutiu, University of South Carolina (United States)

Christopher S. Lynch, University of California, Los Angeles

(United States)

Conference Chair

Henry A. Sodano, University of Florida (United States)

Conference Cochairs

Wei-Hsin Liao, The Chinese University of Hong Kong (Hong Kong, China)

Gyuhae Park, Chonnam National University (Korea, Republic of)

Conference Program Committee

Gregory S. Agnes, Jet Propulsion Laboratory (United States)

Mehdi Ahmadian, Virginia Polytechnic Institute and State University (United States)

Eric H. Anderson, CSA Engineering, Inc. (United States)

Hiroshi Asanuma, Chiba University (Japan)

Amr M. Baz, University of Maryland, College Park (United States)

Diann E. Brei, University of Michigan (United States)

Gregory P. Carman, University of California, Los Angeles

(United States)

Seung-Bok Choi, Inha University (Korea, Republic of)

William W. Clark, University of Pittsburgh (United States)

Alison B. Flatau, University of Maryland, College Park (United States)

Farhan Gandhi, The Pennsylvania State University (United States)

Ephrahim Garcia, Cornell University (United States)

Mehrdad N. Ghasemi-Nejhad, University of Hawai'i at Manoa (United States)

Victor Giurgiutiu, University of South Carolina (United States)

Faramarz Gordaninejad, University of Nevada, Reno (United States)

Nakhiah C. Goulbourne, University of Michigan (United States) 
Tristram Tupper Hyde, NASA Goddard Space Flight Center (United States)

Daniel J. Inman, University of Michigan (United States)

Conor D. Johnson, CSA Engineering, Inc. (United States)

Hyung-Jo Jung, KAIST (Korea, Republic of)

Seung Jo Kim, Seoul National University (Korea, Republic of)

Jeong-Hoi Koo, Miami University (United States)

Wei-Hsin Liao, The Chinese University of Hong Kong (Hong Kong, China)

Roger Ohayon, Conservatoire National des Arts et Métiers (France)

Mohammad Rastgaar Aagaah, Massachusetts Institute of Technology (United States)

Norbert Schwesinger, Technische Universität München (Germany)

Yi-Chung Shu, National Taiwan University (Taiwan)

Steve Southward, Virginia Polytechnic Institute and State University (United States)

Roger Stanway, The University of Sheffield (United Kingdom)

Kon-Well Wang, University of Michigan (United States)

Norman M. Wereley, University of Maryland, College Park

(United States)

Session Chairs

1 Energy Harvesting and Scavenging: General I

Henry A. Sodano, University of Florida (United States)

Wei-Hsin Liao, The Chinese University of Hong Kong (Hong Kong, China)

2 Energy Harvesting and Scavenging: Circuitry

Ephrahim Garcia, Cornell University (United States)

Lei Zuo, Stony Brook University (United States)

3 Energy Harvesting and Scavenging: Broadband Techniques

Hyung-Jo Jung, KAIST (Korea, Republic of)

Yaowen Yang, Nanyang Technological University (Singapore)

4 Biological-inspired Systems and Bio-MEMS

Andy Sarles, The University of Tennessee (United States)

Robert K. Lenzen, Air Force Institute of Technology (Unite States)

5 Energy Harvesting and Scavenging: General II

Gyuhae Park, Chonnam National University (Korea, Republic of)

Amr M. Baz, University of Maryland, College Park (United States) 
6 Modeling, Simulation, Optimization, Signal Processing, Control, and Design of Integration

Mehrdad N. Ghasemi-Nejhad, University of Hawai'i (United States)

Manuel Collet, Université de Franche-Comté (France)

7 Passive and Active Vibration Isolation Systems I

Paul Reynolds, The University of Sheffield (United Kingdom)

8 Magneto Rheological Systems I

Norman M. Wereley, University of Maryland, College Park (United States)

Seung-Bok Choi, Inha University (Korea, Republic of)

9 SMA- and Piezo-Based Materials and Systems

Yirong Lin, The University of Texas at El Paso (United States)

Diann E. Brei, University of Michigan (United States)

10 Aircraft, MAV/UAV and Morphing Systems

Daniel J. Inman, University of Michigan (United States)

Nakhiah C. Goulbourne, University of Michigan (United States)

11 Magneto Rheological Systems II

Mehdi Ahmadian, Virginia Polytechnic Institute and State University (United States)

Henry A. Sodano, University of Florida (United States)

12 Energy Harvesting and Scavenging: General III

William W. Clark, University of Pittsburgh (United States)

Steve Southward, Virginia Polytechnic Institute and State University (United States)

Yi-Chung Shu, National Taiwan University (Taiwan)

Norbert Schwesinger, Technische Universität München (Germany)

13 Modeling of Energy Harvesting Systems I

Ya D. Wang, University of Michigan (United States)

14 Modeling of Energy Harvesting Systems II

Alper Erturk, Georgia Institute of Technology (United States)

Ya D. Wang, University of Michigan (United States)

15 Adaptive Systems and Strategies

Alison B. Flatau, University of Maryland, College Park (United States)

Victor Giurgiutiu, University of South Carolina (United States)

16 Passive and Active Vibration Isolation Systems II

Donald Nyawako, The University of Sheffield (United Kingdom) 
17 Passive and Active Vibration Isolation Systems III

Roger Ohayon, Conservatoire National des Arts et Métiers (France)

Ji Su, NASA Langley Research Center (United States) 